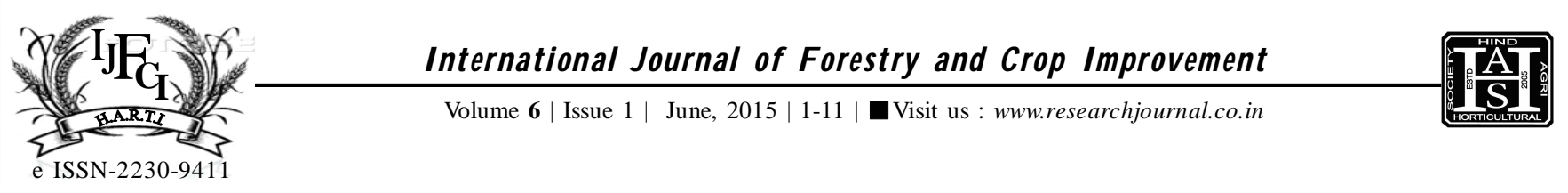

\title{
Effect of organic farming practices on soil properties and beneficial soil micro-organism
}

\author{
RudRagouda F. ChanNAgOUdA, H.B. BABALAD and S.B. SALIMATH
}

\begin{abstract}
The field experiment was carried out at MARS, Dharwad during Kharif 2010-11 and 2011-12 to study the effect of organic farming practices on soil properties and beneficial soil micro-organism among the organic manurial treatments, application of EC (1/3) + VC (1/3) + gliricidia GLM (1/3) equivalent to RDF recorded significantly higher uptake of $\mathrm{N}_{2} \mathrm{P}_{2} \mathrm{O}_{5}$ and $\mathrm{K}_{2} \mathrm{O}(72.53,14.26$ and $77.3 \mathrm{~kg} \mathrm{ha}^{-1}$, respectively) over EC (1/3) + VC (1/3) + GLM (1/3) equivalent to RDN. Among the organic treatment combinations, application of EC (1/3) + VC (1/3) + gliricidia GLM (1/3) equivalent to RDF with foliar spray of Panchagavya @ 5 per cent recorded significantly higher uptake of $\mathrm{N}, \mathrm{P}_{2} \mathrm{O}_{5}$ and $\mathrm{K}_{2} \mathrm{O}\left(73.80,15.16\right.$ and $78.4 \mathrm{~kg} \mathrm{ha}^{-1}$, respectively) over other organic combinations and was at par with $(1 / 3)+\mathrm{VC}(1 / 3)+\mathrm{GLM}(1 / 3)$ equivalent to RDF with borax @ 0.2 per cent + $\mathrm{MgSO}_{4} @ 1$ per cent and RDF + FYM. Among the nutrient management practices, integrated application of EC (1/3) + VC (1/3) + gliricidia GLM (1/3) equivalent to RDF recorded significantly higher available soil $\mathrm{N}, \mathrm{P}_{2} \mathrm{O}_{5}$ and $\mathrm{K}_{2} \mathrm{O}\left(282.5,28.8,328.3 \mathrm{~kg} \mathrm{ha}^{-1}\right.$, respectively) over FYM @ $5 \mathrm{t} \mathrm{ha}^{-1}+\mathrm{RDF}$. Combined application of EC (1/3) + VC (1/3) + GLM (1/3) equivalent to RDF and EC (1/3) + VC (1/3) + GLM (1/3) equivalent to RDN recorded significantly higher organic carbon (5.6 and $5.5 \mathrm{~g} \mathrm{~kg}^{-1}$, respectively) over FYM @ $5 \mathrm{t} \mathrm{ha}^{-1}+\mathrm{RDF}\left(5.2 \mathrm{~g} \mathrm{~kg}^{-1}\right)$. Integrated application of EC (1/3) + VC (1/3) + gliricidia GLM (1/3) equivalent to RDF recorded significantly higher bacteria, fungal, actinomycetes, phosphorus solubilising bacteria, $\mathrm{N}_{2}$-fixers, enzymes mainly phosphatase and dehydrogenase activity and soil respiration rate $\left(73.19 \mathrm{cfu} \times 10^{6} / \mathrm{g}\right.$ of soil, $26.84 \mathrm{cfu} \times 10^{3} / \mathrm{g}$ of soil, $39.65 \mathrm{cfu} \times 10^{2} / \mathrm{g}$ of soil, $26.15 \mathrm{cfu} \times 10^{3} / \mathrm{g}$ of soil, $29.52 \mathrm{cfu} \times 10^{3} /$ $\mathrm{g}$ of soil, $25.01 \mu \mathrm{pnp} / \mathrm{g}$ of soil/hr, $11.99 \mu \mathrm{TPF} / \mathrm{g}$ of soil/day and $9.51 \mathrm{mg}$ of $\mathrm{C}$ or $\mathrm{CO}_{2} / \mathrm{hr} / 100 \mathrm{~g}$ of soil, respectively) at $60 \mathrm{DAS}$ as compared to application of FYM @ $5 \mathrm{t} \mathrm{ha}^{-1}+\mathrm{RDF}$. Among the different treatment combinations, application of EC $(1 / 3)+\mathrm{VC}(1 / 3)$ + gliricidia GLM (1/3) equivalent to RDF with foliar spray of Panchagavya @ 5 per cent recorded significantly higher bacteria, fungi, actinomycetes, $\mathrm{N}_{2}$-fixers and $\mathrm{P}$-solubilizer, phosphatase and dehydrogenase enzyme activity and soil respiration rate over $\mathrm{RDF}+\mathrm{FYM}$.
\end{abstract}

KEY WORDS : Uptake, Soil availability, N, P, K, Microbial population

How TO CITE THIS ARTICLE : Channagouda, Rudragouda F., Babalad, H.B. and Salimath, S.B. (2015). Effect of organic farming practices on soil properties and beneficial soil micro-organism. Internat. J. Forestry \& Crop Improv., 6 (1) : 1-11.

Article ChronicAl : Received : 24.07.2014; Revised : 02.04.2015; Accepted : 05.05.2015

\begin{tabular}{l}
\hline MEMBERS OF RESEARCH FORUM \\
Address of the Correspondence : RUDRAGOUDA. F. CHANNAGOUDA, Krishi \\
Vigyan Kendra (U.A.H.S.), Babbur Farm, Hiriyur, CHITRADURGA (KARNATAKA) INDIA \\
Email: rfc1234@ rediffmail.com \\
Address of the Coopted Authors : H.B. BABALAD, Department of Agronomy, \\
University of Agricultural Sciences, DHARWAD (KARNATAKA) INDIA \\
$\begin{array}{l}\text { S.B. SALIMATH, Krishi Vigyan Kendra (U.A.H.S.), Babbur Farm, Hiriyur, } \\
\text { CHITRADURGA (KARNATAKA) INDIA }\end{array}$
\end{tabular}

